\title{
Modulation of Electrical Synaptic Transmission in Zebrafish Retinal Horizontal Cells
}

\author{
Douglas G. McMahon \\ Department of Physiology and Biophysics, University of Kentucky, Lexington, Kentucky 40536-0084
}

Electrical synaptic transmission is widespread in the vertebrate CNS and its modulation plays a critical role in altering the properties of coupled neural networks. In order to define further the mechanisms of electrical synaptic plasticity in the vertebrate retina, the electrophysiological characteristics of solitary horizontal cells and horizontal cell pairs from the zebrafish (Brachydanio rerio) were examined by wholecell patch-clamp recordings from cells in primary cell culture. In solitary cells, the current-voltage relation exhibited inward current at potentials negative to $-60 \mathrm{mV}$, a linear region of high resistance from $-50 \mathrm{mV}$ to $0 \mathrm{mV}$, and outward current positive to $+20 \mathrm{mV}$. The inward current at negative potentials was blocked by substituting $\mathrm{Cs}^{+}$for $\mathrm{K}^{+}$in the extracellular medium, while the outward current at positive potentials was blocked by substitution of $\mathrm{Cs}^{+}$for $\mathrm{K}^{+}$in the pipette solution. Measurements of gap junctional conductance from electrically coupled cell pairs revealed that zebrafish horizontal cells expressed a mean junctional conductance of considerably smaller magnitude than other teleost retinal horizontal cells. Junctional conductance was found to be voltage dependent, exhibiting time-dependent closure with increasing transjunctional voltage. Voltage sensitivity was symmetrical about $0 \mathrm{mV}$ junctional potential. At $\pm 90 \mathrm{mV}$ the ratio of steady state to peak current was approximately 0.5 and the time constant for inactivation of the junctional current was approximately $120 \mathrm{msec}$. Junctional conductance was also modulated by dopamine and cAMP. Pairs of horizontal cells responded to puff application of dopamine with a two- to threefold reduction in junctional conductance, but there was no discernible effect on extrajunctional conductances. The action of dopamine on coupling was mimicked by application of the dopamine agonist $( \pm$ )-6,7-dihydroxy-2-amino-tetralin (ADTN) and the membrane permeable cAMP analog 8-bromocAMP. The selective $D_{1}$ dopamine receptor antagonist SCH23390 blocked uncoupling by dopamine. These data provide a primary description of the electrophysiological characteristics of solitary horizontal cells and the electrical coupling between pairs of horizontal cells dissociated from the zebrafish retina. They indicate that zebrafish horizontal cells are distinct from the horizontal cells of other teleosts in their coupling characteristics. The results suggest that

\footnotetext{
Received Mar. 29, 1993; revised Aug. 4, 1993; accepted Sept. 2, 1993.

I thank Regina Marcinek for excellent technical assistance, and Dr. Bertram Peretz for comments on a previous version of the manuscript. This research was supported by NIH Grant R29 EY09256 and a grant from the University of Kentucky Medical Center Research Fund.

Correspondence should be addressed to Douglas G. McMahon at the above address.

Copyright (C) 1994 Society for Neuroscience $0270-6474 / 94 / 141722-13 \$ 05.00 / 0$
}

zebrafish horizontal cells exhibit differences in the regulation of synaptic assembly and maintenance that have important implications for the function of the zebrafish horizontal cell network in vivo.

[Key words: gap junction, synaptic plasticity, neuromodulation, electrical coupling, patch clamp, visual adaptation, zebrafish]

Modulation of synaptic communication between neurons is a fundamental mechanism by which the nervous system responds to changes in environmental stimuli, reflects previous experience, and shapes functional connections during development. Of the two forms of synaptic transmission, chemical and electrical, most studies of synaptic plasticity have focused on the modulation of chemical synapses. However, electrical synapses and their structural basis, gap junctions, are also widely distributed in the vertebrate CNS (Llinas, 1985), including the developing cortex (Connors et al., 1983), the adult hippocampus (MacVicar and Dudek, 1981), striatum (Cepeda et al., 1989), nucleus accumbens (O'Donnell and Grace, 1991), locus coeruleus (Christie et al., 1989), inferior olive (Llinas, 1985), and retina (cf. Dowling, 1987), where they are thought to synchronize production of action potentials by electrically coupled neurons, allow propagation of subthreshold potentials in coupled networks of neurons, and participate in defining neuronal groups during development (Yuste et al., 1992; Peinado et al., 1993). Electrical synaptic transmission, or its correlate, neuronal dye coupling, is modulated in the retina and basal ganglia by the catecholamine neurotransmitter dopamine (Negishi and Drujan, 1979; Teranishi et al., 1983; Lasater and Dowling, 1985a; Cepeda et al., 1989; O'Donnell and Grace, 1991; Onn et al., 1991), in brain regions associated with reproductive function by steroid hormones (Cobbett et al., 1987; Matsumoto et al., 1988), and in the hippocampus, a critical site for memory formation, during aging and senescence (Barnes et al., 1987).

In the first synaptic layer of the retina, where the initial steps of visual information processing take place, electrical synapses play a critical role in transmitting and encoding visual signals. Retinal horizontal cells, second-order neurons postsynaptic to photoreceptors, are electrically coupled through gap junctional synaptic contacts to form a network for the lateral transmission of inhibitory signals in the outer retina (cf. Dowling, 1987). Lateral inhibition mediates the antagonistic center-surround organization of bipolar and ganglion cell receptive fields and therefore represents the initial steps of encoding spatial information in visual signals. In several vertebrate species, the synaptic physiology of horizontal cells and, thus, the functional properties of the spatially ordered retinal neural network are modulated by the neurotransmitter dopamine (Negishi and Drujan, 1979; Pic- 
colino et al., 1984; Dong and McReynolds, 1991; Hampson et al., 1992). In the retinas of teleost fish, cone-driven horizontal cells receive modulatory synaptic input from dopaminergic interplexiform cells (Dowling and Ehinger, 1978). Dopamine has been found to uncouple teleost horizontal cells through activation of adenylate cyclase and protein kinase A (Van Buskirk and Dowling, 1981; Lasater and Dowling, 1985a; Lasater, 1987; DeVries and Schwartz, 1989). Neither the precise molecular mechanisms of electrical synaptic modulation nor the implications of this plasticity for overall visual performance of the retina have been defined. Resolution of these questions will require a combination of electrophysiological, molecular, and behavioral approaches to understanding retinal synaptic plasticity.

The zebrafish (Brachydanio rerio) is a potentially advantageous preparation for such an integrated approach to understanding synaptic modulation and its role in retinal function. Methods for production and maintenance of transgenic animals (Stuart et al., 1988; Culp et al., 1991), insertional mutagenesis (Fulwiler et al., 1992), and propagation of genetic mutant strains as homozygous clones (Streisinger et al., 1981) as well as psychophysical tests of visual function (Clark, 1981) have been described for zebrafish. However, the electrophysiology of zebrafish retinal neurons has not yet been explored, and while the presence of dopaminergic interplexiform cells in the zebrafish retina has been confirmed (Fulwiler et al., 1989), the effects of dopamine on retinal neurons and synapses are also uncharacterized.

In this study, the electrophysiological characteristics of zebrafish retinal horizontal cells in dispersed cell culture were examined using whole-cell patch-clamp recording of individual cells and dual whole-cell patch-clamp recording from electrically coupled cell pairs. The results provide a primary description of the ionic currents expressed by these retinal neurons, the characteristics of their electrical coupling in vitro, and the modulation of coupling by voltage, dopamine, and cAMP. The findings demonstrate that zebrafish horizontal cell pairs are unique among the teleosts in that they express a small-magnitude junctional conductance. They establish the physiological basis for electrical synaptic plasticity in the zebrafish retina, and provide the foundation for studies of the molecular mechanisms and functional implications of modulation at these neuronal electrical synapses. In addition, the quantitative differences in zebrafish horizontal cell coupling and its modulation suggest that there are important differences in the function of the horizontal cell network and in the mechanisms that regulate the expression of electrical coupling in this organism compared with other teleosts.

Some of the results reported here have already appeared in abstract form (McMahon, 1992; McMahon and Marcinek, 1992).

\section{Materials and Methods}

Cell culture. Dark-adapted adult zebrafish were killed in accordance with NIH guidelines for animal use. Retinas were removed under dim red light, rinsed in L-15 media (Sigma) containing 5-10× penicillin/ streptomycin, and then incubated for $30 \mathrm{~min}$ at room temperature in L-15 media containing $20 \mathrm{U} / \mathrm{ml}$ papain (Worthington) activated with $0.3 \mathrm{mg} / \mathrm{ml}$ cysteine. Retinas were then washed with six changes of fresh L-15 media, dissociated by repeated passage through a serological pipette, or the trimmed tip of a $1 \mathrm{ml}$ pipette aid, and plated onto plastic dishes containing a medium composed of (mM) $137 \mathrm{NaCl}, 2.5 \mathrm{KCl}, 0.5$ $\mathrm{MgCl}_{2}, 0.5 \mathrm{MgSO}_{4}, 2.625 \mathrm{CaCl}_{2}, 1 \mathrm{Na}$-pyruvate, $0.5 \mathrm{NaHCO}_{3}, 0.5$ $\mathrm{NaH}_{2} \mathrm{PO}_{4}, 10$ HEPES, 16 glucose, $1 \mathrm{mg} / \mathrm{ml}$ BSA (Sigma, fraction VII), $1 \times$ penicillin/streptomycin, $\mathrm{pH}$ to 7.5 with $\mathrm{NaOH}$ (modified from Tach-

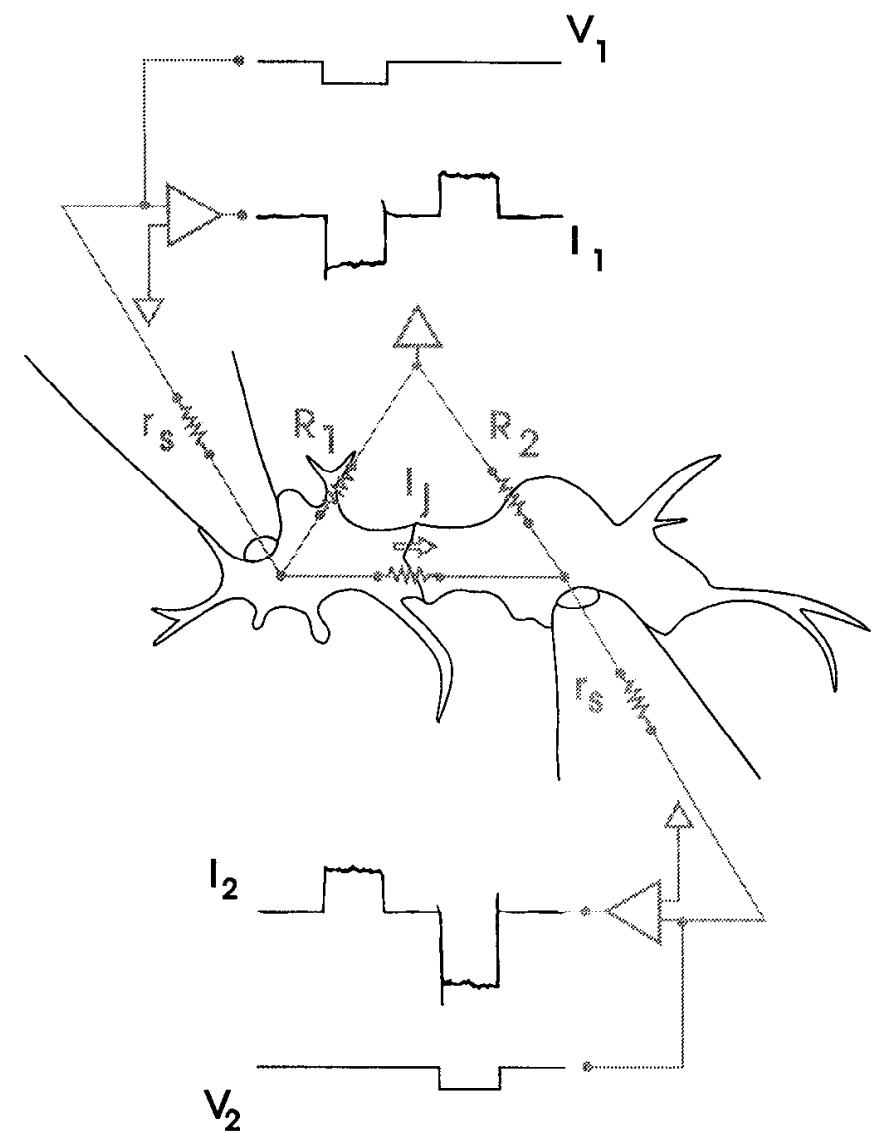

Figure 1. Dual whole-cell patch-clamp recording configuration. Outline of a pair of horizontal cells with patch electrodes in whole-cell configuration is shown in the solid line, while the equivalent circuit is shown in broken lines. In the equivalent circuit, $r_{s}$ in each electrode represents the series resistance, $R_{1}$ and $R_{2}$ represents the resistance of the extrajunctional membrane in cells 1 and 2 , respectively, and $I_{j}$ represents the junctional current that flows in response to a voltage step. Traces above and below show command potential $\left(V_{1}, V_{2}\right)$ and holding current $\left(I_{t}, I_{2}\right)$ from each cell of a pair during reciprocal voltage steps.

ibana, 1983). Cultures were maintained at room temperature $\left(22^{\circ} \mathrm{C}\right)$ and were viable for 7-10 d.

Recording. Recordings were performed using the whole-cell patchclamp technique (Hamill et al., 1981). Patch pipettes (5-10 M 2 ) were fabricated of Corning 7052 glass (AM Systems) and filled with a solution consisting of (mM) $120 \mathrm{~K}$-gluconate, $4 \mathrm{KCl}, 1 \mathrm{CaCl}_{2}, 11 \mathrm{EGTA}, 10$ HEPES, $1 \mathrm{Mg}$-ATP, $0.1 \mathrm{Na}-\mathrm{GTP}, \mathrm{pH}$ to 7.5 with $\mathrm{KOH}$ (modified from Perlman et al., 1988). The extracellular solution was the above-mentioned culture medium. For experiments involving blockage of $\mathrm{K}^{+}$currents, the $120 \mathrm{~mm}$ Cs-gluconate and $4 \mathrm{~mm} \mathrm{CsCl}$ were used in the intracellular solution, while $10 \mathrm{~mm} \mathrm{CsCl}$ was substituted for the $4 \mathrm{~mm} \mathrm{KCl}$ in the extracellular solution. Whole-cell currents were recorded using an Axopatch 1-D amplifier (Axon Instruments, Foster City, CA) in voltage-clamp mode. Voltage commands, data acquisition, and analysis were performed using pCLAMP and AXOTAPE software (Axon Instruments).

Recordings from solitary neurons were obtained using conventional whole-cell patch-clamp recording, while electrical synaptic transmission between pairs of horizontal cells was examined using the dual wholecell patch-clamp configuration shown in Figure 1 (Neyton and Trautmann, 1985). For dual wholc-ccll recording, a patch pipette was attached to each cell of a pair, and each was then voltage clamped with an independent amplifier. As shown in Figure 1, a voltage step imposed on one cell of the pair (cell 1) results in a change in the holding current of the contralateral cell (cell 2), due to the transjunctional current, $I_{j}$, generated by the transjunctional voltage difference, $V_{j}$. As shown by the equivalent circuit in Figure $1, V_{j}$ is the difference in the holding potentials of the driver cell $\left(V_{1}\right)$ and the follower cell $\left(V_{2}\right)$, minus the voltage errors 

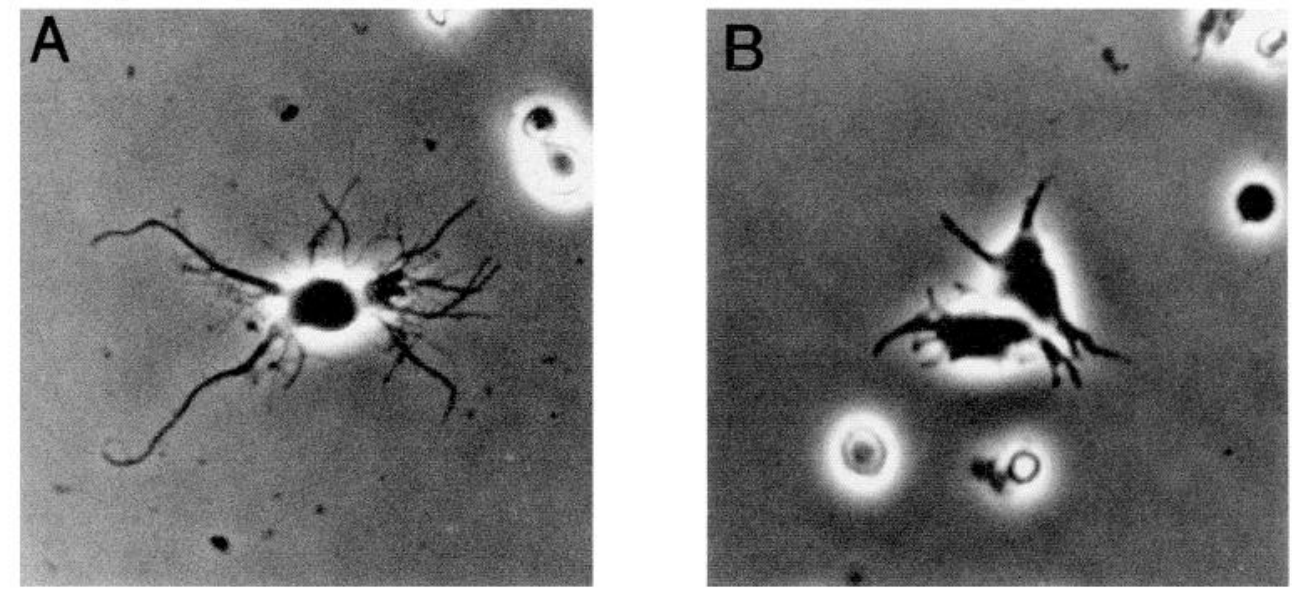

Figure 2. Zebrafish horizontal cells in primary cell culture. Photomicrographs show a solitary horizontal cell $(A)$ and a cell pair $(B)$.

\section{$30 \mathrm{uM}$}

in each holding potential due to pipette series resistance. The errors due to uncompensated series resistance are additive because the currents are opposite in sign (see Fig. 1). This is expressed by

$$
V_{j}=\left(V_{1}-V_{2}\right)-\left(r_{\text {series } 1} \cdot I_{1}-r_{\text {series } 2} \cdot I_{2}\right)
$$

Similarly, $I_{j}$ is the current recorded in cell $2\left(I_{2}\right)$ in response to the voltage step in cell 1 , plus the fraction of $I_{j}$ that passes through the membrane of cell 2 rather than through the recording pipette, as expressed by

$$
I_{j}=I_{2} \cdot\left(1+r_{\text {series } 2} / R_{2}\right)
$$

In the experiments on resting junctional conductance and its modulation by dopaminergic agents, the error introduced by uncompensated series resistance was minimal, so the transjunctional voltage, $V_{j}$, was approximated as $V_{j}=V_{1}-V_{2}$; the junctional current, $I_{j}$, as $I_{j}=I_{2}$; and the junctional conductance, $G_{j}$, as $G_{j}=I_{j} / V_{j}$. With regard to the error in $V_{j}$, the mean value of $I_{1}$ was $181 \mathrm{pA}$, and of $I_{2}$ was $133 \mathrm{pA}$, for cell pairs used in this study; series resistance, measured by the compensation circuit during recording, was typically $15 \mathrm{M} \Omega$, and $10 \mathrm{M} \Omega$ compensation was typically applied. By Equation 1 above, the approximation overestimated actual junctional voltage by $3 \mathrm{mV}(7.5 \%)$ on average. With regard to the error in $I_{j}$, the mean extrajunctional membrane resistance, $R_{2}$, for the cell pairs used in this study was $3.7 \mathrm{G} \Omega$, and by Equation 2, $I_{2}$ differs from $I_{j}$ by less than $1 \%$. Because of the larger-amplitude currents involved, voltage-clamp errors were larger at the high transjunctional voltages used to study voltage-dependent gating. This artifactually reduced the apparent extent of inactivation with increasing junctional voltage and lengthened the apparent time course of inactivation.

Pharmacological agents were prepared fresh daily as $10 \mathrm{~mm}$ stocks in $1 \mathrm{mg} / \mathrm{ml}$ ascorbate $[( \pm)$-6,7-dihydroxy-2-amino-Tetralin (ADTN), dopamine, apomorphine], water (SCH23390, 8-bromo-cAMP, SKF38393), or dilute lactic acid (haloperidol), diluted to working concentrations with culture media, and applied by pressure ejection from broken patch pipettes placed near the cell pair. Pressure pulses were 2-4 sec in duration, and were controlled by a Picospritzer (General Valve). It is estimated that the actual concentration of agonist at the target cells was about one-half of its concentration in the application pipette due to diffusion (Knapp and Dowling, 1987). Concentrations in text are pipette concentrations. $R(-)$-apomorphine, $( \pm)-6,7-\mathrm{ADTN}, R(+)-\mathrm{SKF} 38393$, and $R(+)-\mathrm{SCH} 23390$ were purchased from Research Biochemicals Inc. (Natick, MA), while dopamine, haloperidol, 8-bromo-cAMP, tetraethylammonium (TEA), and 4-aminopyridine (4-AP) were purchased from Sigma (St. Louis, MO).

\section{Results}

Morphology of zebrafish horizontal cells in vitro

Dissociation of zebrafish retinas into primary cell culture yields a variety of cell types readily identifiable by morphology (e.g., rods and cones, bipolar cells, horizontal cells), and numerous rounded cells of ambiguous identity. Horizontal cells were identified by their distinctive multipolar morphology and were generally $10-15 \mu \mathrm{m}$ in diameter at the cell body (Fig. 2). In other teleost species up to four morphologically distinct subtypes of horizontal cells, termed $\mathrm{H} 1-\mathrm{H} 4$, have been identified in cell culture (Dowling et al., 1982). In the zebrafish retinal cultures used for this study, at least two morphological subtypes of horizontal cells could be identified. The majority of cells resembled H1-type cells as described in other teleosts (Fig. 2A,B), while the second, more rarely observed subtype (not shown) resembled H3-type cells. More precise definition of horizontal cell subtypes in the zebrafish will require correlation of in vivo and in vitro morphology. All recordings reported here are from putative $\mathrm{H} 1$ type cells, which in other teleosts are cone driven (Stell and Lightfoot, 1975) and receive synaptic input from dopaminergic interplexiform cells (Dowling and Ehinger, 1978).

\section{Characteristics of solitary cells}

Figure $3 A$ shows average membrane currents observed during whole-cell patch-clamp recording of the steady state currentvoltage relation from six solitary horizontal cells. The cells were voltage clamped at a holding potential of $-60 \mathrm{mV}$, and then the membrane potential was stepped from -120 to $+70 \mathrm{mV}$ in $10 \mathrm{mV}$ increments. As shown in the current-voltage relation (Fig. $3 B$ ), there is a prominent inward rectifying current activated at potentials negative to $-60 \mathrm{mV}$, a notable lack of membrane current between $-60 \mathrm{mV}$ and $0 \mathrm{mV}$, and outward current at potentials positive to $+20 \mathrm{mV}$. The "flat spot" of linear high resistance in the current-voltage relation, extending from approximately 0 to $-50 \mathrm{mV}$, provided a range of membrane potentials over which the junctional conductance of cell pairs could be assayed with minimal activation of extrajunctional conductances. The steady state currents outside the linear high-resistance region have characteristics consistent with inward-rectifying and delayed-rectifying potassium currents previously observed in teleost retinal horizontal cells (Shingai and Christensen, 1988; Tachibana, 1983; Lasater, 1986; Sullivan and Lasater, 1990). Further indication that these are indeed potassium currents was obtained by experiments replacing $\mathrm{K}^{+}$with $\mathrm{Cs}^{+}$ 
in the extracellular medium or in the recording pipette. As shown in Figure $3 C$, replacement of the $\mathrm{K}^{+}$in the extracellular medium with $10 \mathrm{~mm} \mathrm{Cs}^{+}$blocked the inward current ( $N=5$ cells), as has been shown for the inward-rectifying $\mathrm{K}^{+}$current in other teleost horizontal cells (Tachibana, 1983; Lasater, 1986). Outward currents at positive potentials were increased during this treatment. Internal perfusion of the cells with $\mathrm{Cs}^{+}$, by substituting this ion for $\mathrm{K}^{+}$in the pipette solution, blocked the outward currents observed at depolarized potentials $(N=6)$ and the inward rectifier (Lasater, 1986), leaving only leak currents (Fig. 3C). Bath application of the $\mathrm{K}^{+}$channel blockers TEA (6.7-10 $\mathrm{mm}$, two cells) and 4-AP ( $7.5 \mathrm{~mm}$, two cells) in the presence of intracellular $\mathrm{Cs}^{+}$had little additional effect on the outward currents. In addition to the inwardly rectifying and sustained outward potassium currents, a minority of solitary cells recorded from under these conditions expressed an additional small-amplitude steady state inward current that was maximal at approximately $+20 \mathrm{mV}$ (see Fig. 9). This current has activation characteristics consistent with a voltage-activated calcium current. Further study will be needed to fully characterize this current.

\section{Electrical coupling}

Approximately $5 \%$ of horizontal cells in these cultures werc contacting cell pairs. The resting conductance of electrical synapses between cell pairs was measured using dual whole-cell patch-clamp recording. A patch pipette was attached to each cell of a pair, and each was then voltage clamped with an independent amplifier. As shown in Figure 1, a voltage step imposed on one cell of the pair (cell 1) results in a change in the holding current of the second cell (cell 2), due to the transjunctional current, $I_{j}$, generated by the transjunctional voltage difference, $V_{j}$. Typically, both cells of a pair were voltage clamped to a holding potential of $0 \mathrm{mV}$, and then alternating $250 \mathrm{msec}$ steps of $-40 \mathrm{mV}$ were applied to each cell at $15 \mathrm{sec}$ intervals (see sample traces, Fig. 1). This procedure minimized the contribution of conductances in the extrajunctional membranes (see Fig. 3) and voltage-dependent closure of the gap junctions (see below). Junctional current, as represented by the current induced in the follower cell by a voltage step applied to the driver cell, was measured for the first 45-60 sec interval following the onset of a stable recording, and the average junctional conductance for that interval was calculated as $G_{j}=I_{j} / V_{j}$ (see Materials and Methods). A summary histogram of the calculated junctional conductances of 60 cell pairs is shown Figure $4 A$. Junctional conductance ranged from 0.1 to $15 \mathrm{nS}$ with a mean of $3.2 \mathrm{nS}$ ( $13.3 \mathrm{SD}$ ). IIalf of the cell pairs exhibited $1-2 \mathrm{nS}$ conductance. In contrast, pairs of horizontal cells from other teleost species commonly exhibit $10-20 \mathrm{nS}$ of junctional conductance (I asater

Figure 3. A, Average voltage-dependent currents from six solitary horizontal cells. Cells were held at $-60 \mathrm{mV}$ and the voltage stepped from $-120 \mathrm{mV}$ to $+70 \mathrm{mV}$ in $10 \mathrm{mV}$ steps of $250 \mathrm{msec}$ in duration. $B$, Steady state current-voltage relation from the six cells in $A$. Steady state currents were measured as an avcragc of 20 digital samples $(20 \mathrm{mscc})$ in the section of the responses from 125 to $245 \mathrm{msec}$ after the onset of the voltage step. Values are mean \pm SEM. $C$, Steady state currentvoltage relation, determined and reported as in $B$, with $\mathrm{Cs}^{+}$substituted for $\mathrm{K}^{+}$in the extracellular solution (squares) or the intracellular solution (triangles). Note blockade of the inwardly rectifying current by extracellular $\mathrm{Cs}^{+}$, and both the inward and outward potassium currents by intracellular $\mathrm{Cs}^{+}$.
A

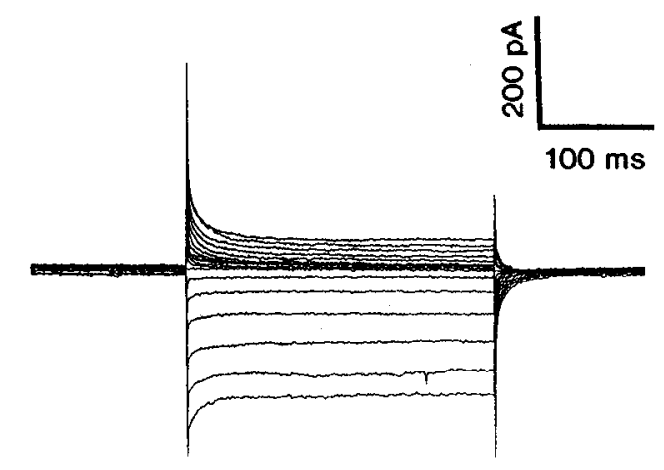

B

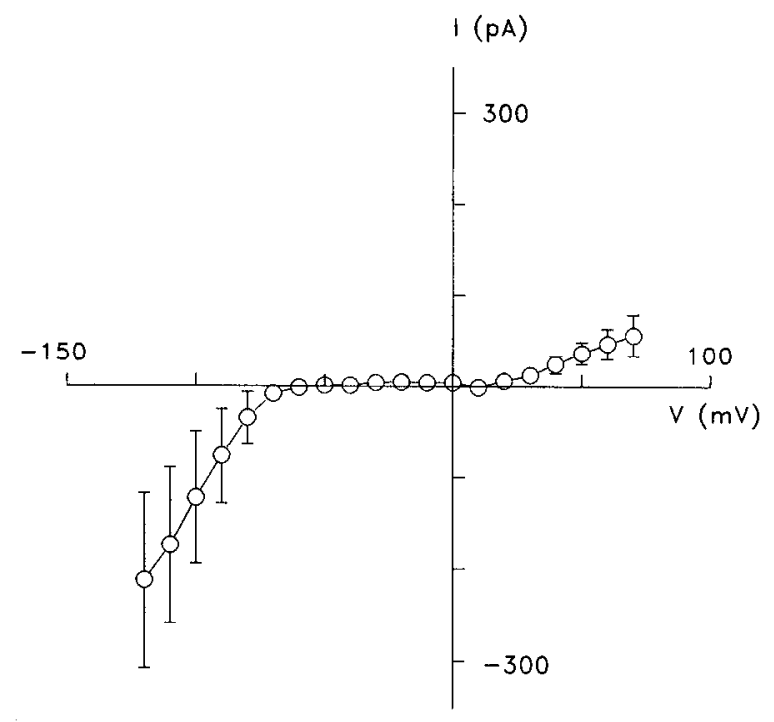

C

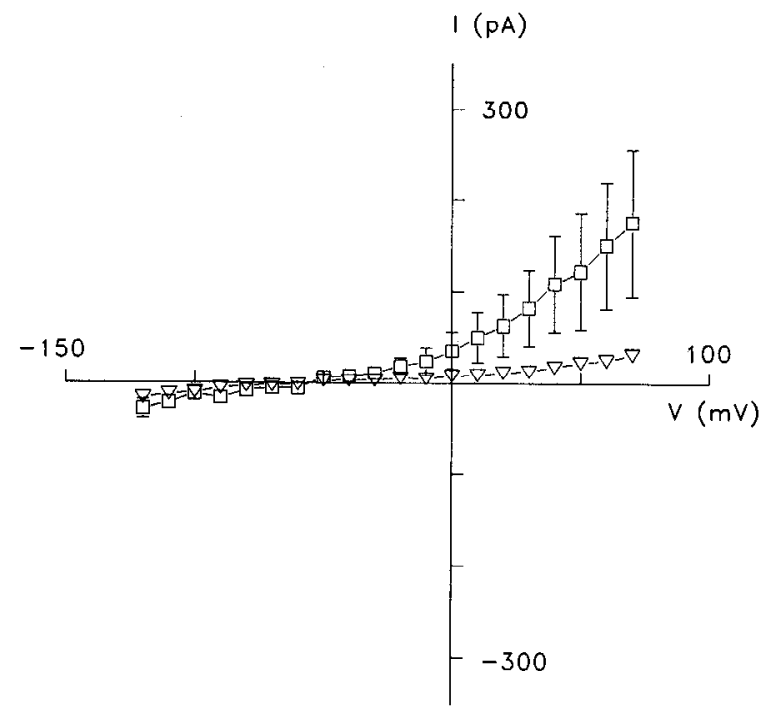


A

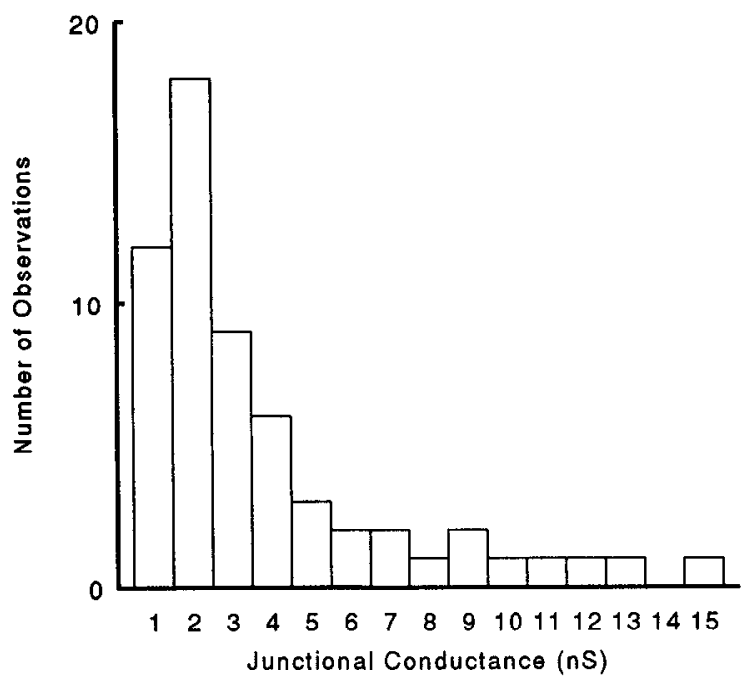

B

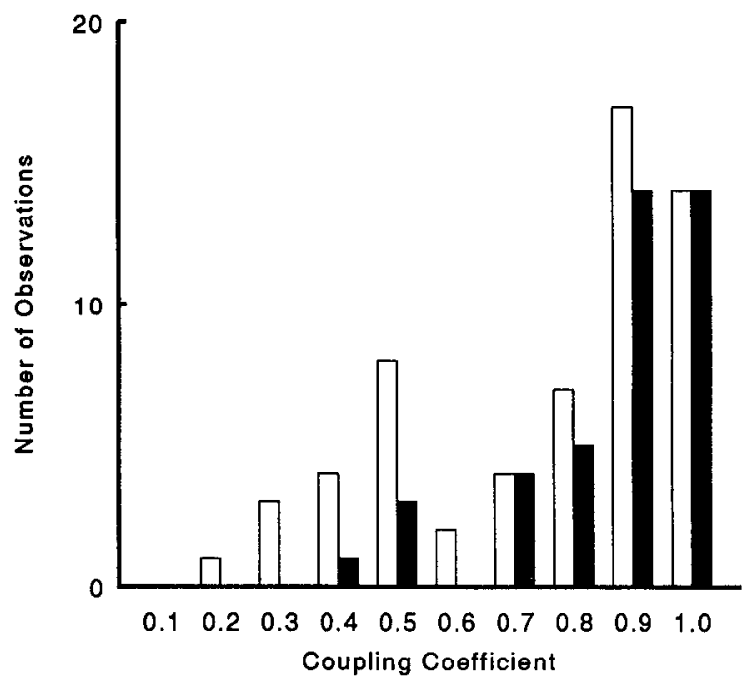

Figure 4. A, Histogram of gap junctional conductance in 60 cell pairs. $B$, Histogram of coupling coefficients for the same 60 cell pairs (white bars), and histogram of coupling coefficients for all cell pairs with input resistances of $1 \mathrm{G} \Omega$ or greater (black bars; 40 pairs). Note the reduction in the proportion of cell pairs with low coupling coefficients that occurs when the low-input-resistance cells are excluded.

and Dowling, 1985a; Lasater, 1987; DeVries and Schwartz, 1989). In order to facilitate accurate measurement of changes in junctional conductance, cell pairs with an initial junctional conductance greater than $1 \mathrm{nS}$ were generally used in experiments investigating voltage dependence and modulation of electrical synaptic transmission. The vast majority of cell pairs used for recording exhibited soma-to-soma contact as shown in Figure $2 B$, which is characteristic of synapses extant at the time of retinal dissociation, rather than the process-to-process contact characteristic of synapses formed de novo in culture.

The small magnitude of the junctional conductance of zebrafish horizontal cells was surprising given that they are as- sumed to function as an electrically coupled network in the retina. Calculation of the coupling coefficient, expressed as the fraction of total membrane current that flowed across the electrical synapse as junctional current in response to a voltage step in one cell of the pair, showed that despite their low junctional conductance zebrafish horizontal cells exhibited a high coupling coefficient. Figure $4 B$ (white bars) shows a summary histogram of the coupling coefficients, calculated as $I_{j} / I_{1}$, for the same 60 cell pairs as the junctional conductance measurements in Figure $4 A$. The mean coupling coefficient was found to be $0.71( \pm 0.24$ $\mathrm{SD}$; white bars). However, the distribution was markedly bimodal with a significant number of cells having coupling coefficients of 0.5 or less. This bimodality in the coupling coefficient is likely the result of injury to some of the cell pairs in the recording process, rather than an inherent property of the gap junctions themselves. When cell pairs with mean extrajunctional membrane resistances of less than $1 \mathrm{G} \Omega$ were excluded from the analysis, the number of pairs with coupling coefficients 0.5 or below was greatly reduced, from 16 to 4 pairs, and the mean coupling coefficient increased to $0.82( \pm 0.16 \mathrm{SD}, N=40$; black bars). Following exclusion of these cell pairs, both the relatively low mean junctional conductance $(3.1 \mathrm{nS}, \pm 3.1 \mathrm{SD}, N=40)$ and the low sensitivity of these gap junctions to dopamine (see below) persist, indicating that these properties are inherent to the junctions themselves and are not due to damage of the cells during recording.

\section{Voltage dependence of coupling}

In a number of biological systems, including mammalian liver cells (Spray et al., 1991), Drosophila salivary gland cells (Verselis et al., 1991), amphibian blastomeres (Harris et al., 1981), and the crayfish giant axon (Furshpan and Potter, 1959; Giaume et al., 1987), gap junctional conductance is gated by transjunctional voltage differences. Current-voltage relations for zebrafish horizontal cell gap junctions were obtained by voltage clamping both cells to an initial holding potential of $0 \mathrm{mV}$, and then applying a series of voltage steps to one cell of the pair. Steps were $1-2.5 \mathrm{sec}$ in duration and ranged from -90 to $+90 \mathrm{mV}$ in $10 \mathrm{mV}$ increments. The responses to one such set of voltage steps are shown in Figure 5, where $V_{1}$ and $I_{1}$ represent the holding potential and current recorded from the driver cell, and $V_{2}$ and $l_{2}$ the holding potential and current recorded from the follower cell. As can be seen in the figure, there is a prominent time-dependent decrease in the junctional current recorded in the follower cell at large transjunctional voltages of both polarities, indicating voltage-dependent inactivation of the junctional conductance. Of 27 cell pairs tested in this manner, 22 exhibited voltage-dependent inactivation of junctional conductance. While the expression of voltage dependence was a consistent finding, the degree of inactivation varied among preparations, ranging from $10 \%$ to $85 \%$ at $\pm 90 \mathrm{mV}$ junctional voltage. To characterize this phenomenon further, the data from six pairs exhibiting strong voltage dependence were subjected to additional analysis.

Figure $6 \mathrm{~A}$ shows in more detail the inactivation of junctional currents recorded in a single cell pair in response to a series of $2.5 \mathrm{sec}$ steps in the transjunctional voltage. The current-voltage relations of the peak and steady state junctional conductance for this preparation are shown in Figure $6 B$. Peak junctional current was measured $6 \mathrm{msec}$ after the voltage step, and steady state current was measured as the average of $40 \mathrm{msec}$ of data (20 digital samples) in the latter half of the voltage step (i.e., from 1.25 to $2.5 \mathrm{sec}$ ). There was rectification of the steady state 

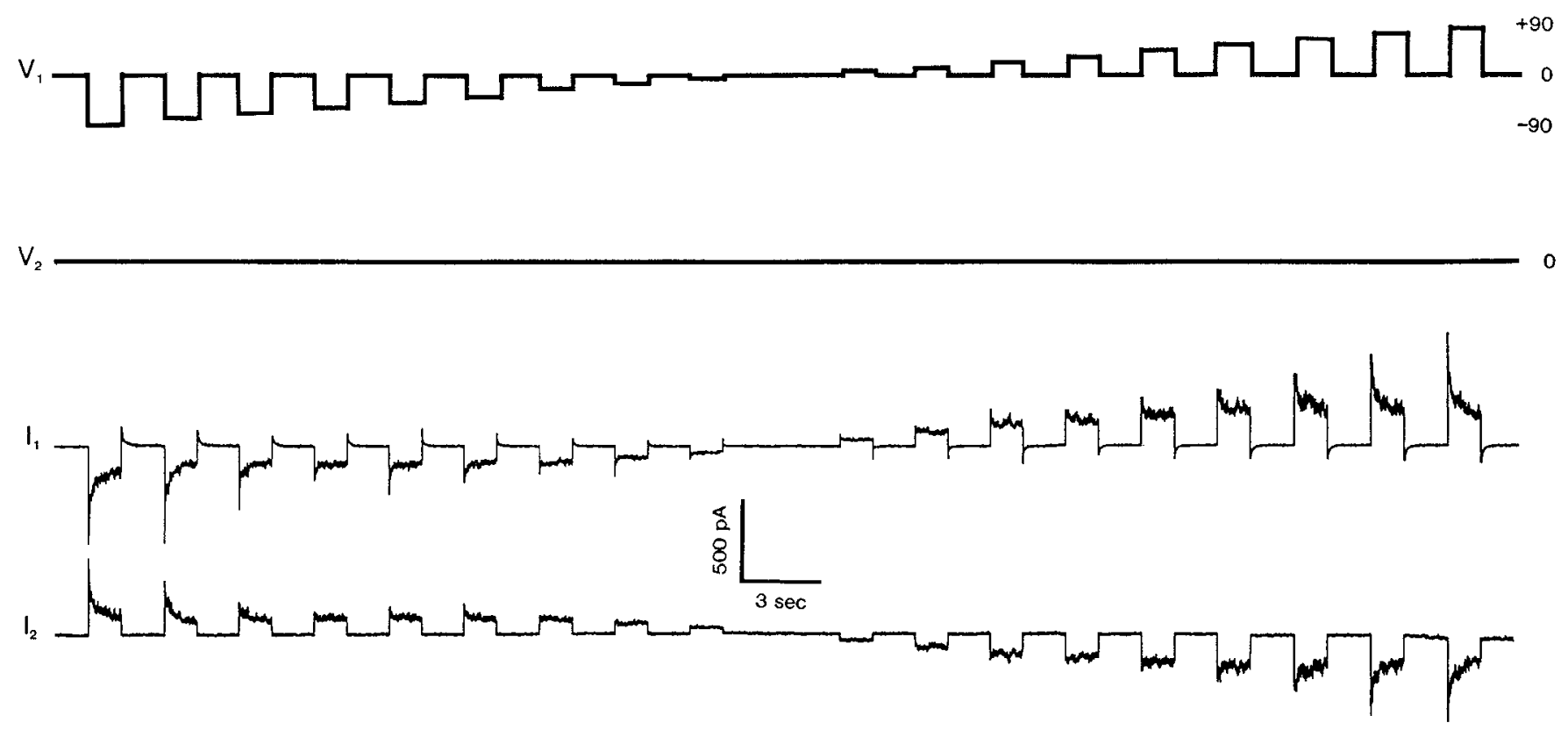

Figure 5. Voltage-dependent inactivation of junctional conductance. Traces show command potential $\left(V_{1}, V_{2}\right.$, hand drawn) and holding current $\left(I_{1}, I_{2}\right)$ recorded from a pair of cells. The holding potential of both cells was $0 \mathrm{mV}$ and the voltage in cell $1\left(V_{1}\right)$ was stepped from -90 to +90 $\mathrm{mV}$ in $10 \mathrm{mV}$ increments. The resulting current in cell 1 and the transjunctional current in cell 2 are shown. Time-dependent inactivation of $I_{2}$ is evident at transjunctional potentials greater than $\pm 40 \mathrm{mV}$.

current compared to the peak current that was most evident at transjunctional voltages positive to $40 \mathrm{mV}$ and negative to -40 $\mathrm{mV}$. Summary data, plotting the ratio of the steady state junctional current to the peak junctional current for six preparations, are shown in Figure $7 \mathrm{~A}$. The average voltage dependence of inactivation was symmetrical about the reversal potential of 0 $\mathrm{mV}$, although individual preparations showed some asymmetry (Fig. $6 B$ ). The average ratio of the steady state to peak junctional current ranged from near unity at $\pm 10 \mathrm{mV}$ to approximately 0.5 at $\pm 90 \mathrm{mV}$, similar to the inactivation observed for cloned human cx43 (Moreno et al., 1992). The degree of inactivation at high transmembrane voltages was likely underestimated to some degree due to voltage-clamp errors introduced by pipette series resistance (see Methods).

The kinetic properties of voltage-dependent inactivation were also investigated. In most traces the time course of inactivation was adequately described by a single exponential, similar to findings in amphibian blastomeres (Harris et al., 1981). Figure $7 B$ shows the junctional current recorded in a follower cell in response to a transjunctional voltage step of $+90 \mathrm{mV}$ in a driver cell. The fitted curve is a single exponential with a time constant of 133 msec. For the six cell pairs analyzed, time constants of channel inactivation at $\pm 90 \mathrm{mV}$ ranged from 57 to $185 \mathrm{msec}$, with a mean of $117 \mathrm{msec}( \pm 40.1 \mathrm{SD}, N=12)$. The mean correlation coefficient for these single exponential fits was 0.89 $( \pm 0.11 \mathrm{SD})$, further indicating the adequacy of single exponentials in describing this decay; however, because voltage-clamp errors associated with the larger holding currents generated at high transjunctional voltages serve to distort the kinetics of inactivation (see Materials and Methods), I cannot exclude the possibility that there are additional exponential components to the time course of inactivation that are not apparent in my records. To determine if the time constant for inactivation varied with transjunctional voltage, the responses recorded at \pm 60 $\mathrm{mV}$ were also analyzed. Time constants at this voltage were longer in duration than at $\pm 90 \mathrm{mV}$, and varied from 73 to 329 msec with a mean of $184 \mathrm{msec}( \pm 88.3 \mathrm{SD}, N=8)$. The remaining four records at this voltage could not be fit reliably. This difference in the mean time constants for inactivation was statistically significant ( $p<0.05, t$ test).

\section{Modulation of coupling by dopamine and CAMP}

Dopamine is a modulatory neurotransmitter in the vertebrate retina, and in the zebrafish as in other teleosts horizontal cells are innervatcd by dopamincrgic interplexiform cells (Fulwiler et al., 1989). The effects of dopamine and dopaminergic agonists and antagonists on electrical coupling between zebrafish horizontal cells were tested by pressure ejecting short-duration puffs (2-4 sec) of pharmacological agents onto cell pairs while monitoring junctional conductance. Cells were voltage clamped to a holding potential of $0 \mathrm{mV}$, and then alternating pulses of -40 $\mathrm{mV}$ were applied at $15 \mathrm{sec}$ intervals. Application of $50 \mu \mathbf{M}$ dopamine resulted in uncoupling in 9 of 10 horizontal cell pairs tested. An example experiment is shown in Figure 8, where the main panel shows the junctional current versus time, and to the right are sample traces from the indicated times during the record. In this experiment, application of dopamine reduced junctional current to approximately one-third or $32 \%$ of its initial value. This effect peaked $30-60 \mathrm{sec}$ after application, and was reversible, with recovery to approximately $75 \%$ of initial coupling completed in approximately $5 \mathrm{~min}$. This timc coursc of onset and recovery was typical of the nine other cell pairs that responded to dopamine, and is appropriate for a process mediated by an intracellular second messenger. The mean fractional junctional current recorded at the peak of the response to $50 \mu \mathrm{M}$ dopamine was 0.53 of the predopamine value $( \pm 0.22$ $\mathrm{SD}, N=9$ ), as shown in summary Figure 13. Application of $100 \mu \mathbf{M}$ dopamine also produced uncoupling in 9 of 10 tested cell pairs, with a similar time course. Dopamine was only slightly 
A

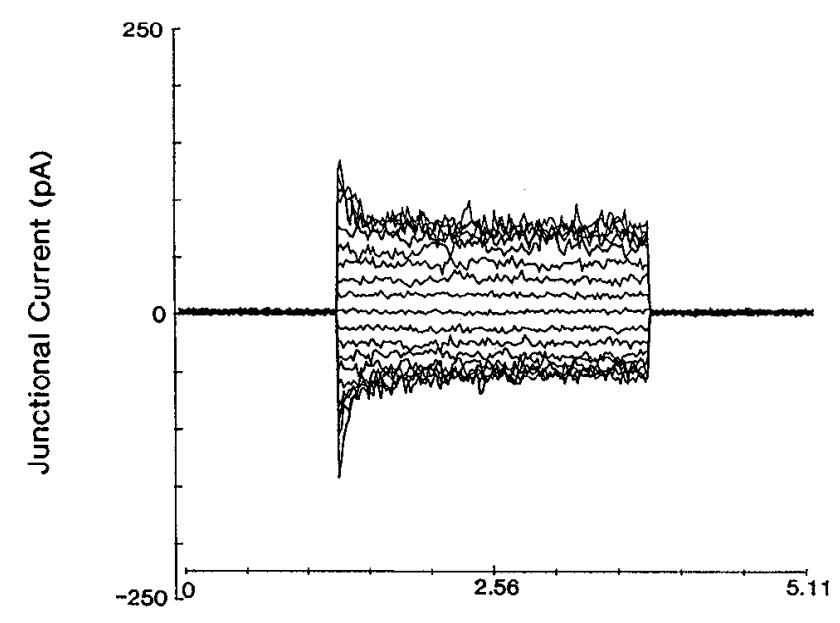

Time (sec)

B

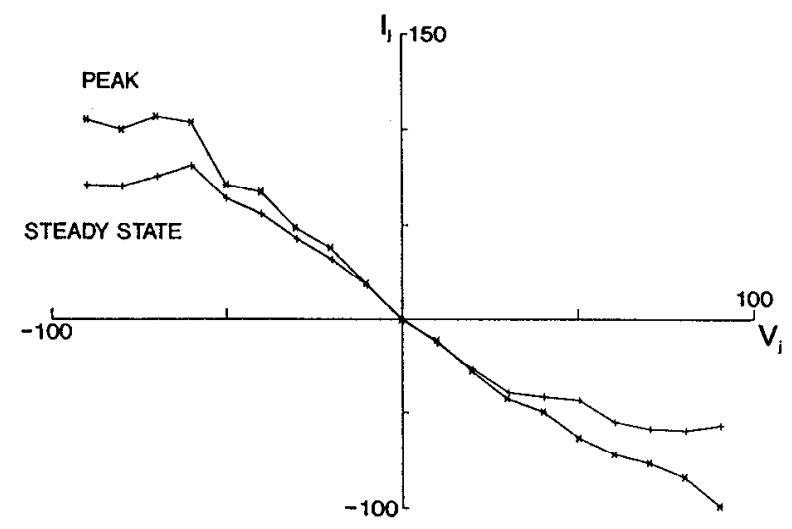

Figure 6. $A$, Inactivation of junctional conductance in response to voltage steps from -90 to $+90 \mathrm{mV}$. $B$, Peak versus steady state junctional conductance. Current is plotted versus the holding potential of the driver cell.

more effective at this concentration, with a mean fractional junctional current of $0.41( \pm 0.16 \mathrm{SD}, N=9)$.

While dopamine had significant effects on junctional conductance, its effects on extrajunctional conductances were minimal. Figure 9 shows steady state current-voltage relations from a solitary horizontal cell taken before and approximately $30 \mathrm{sec}$ after application of $50 \mu \mathrm{M}$ dopamine. The only apparent change is a slight shift in activation of the inward-rectifying current to more negative potentials. This is most likely an effect of the pressure ejection itself rather than an effect of dopamine (Perlman et al., 1988). Importantly, there is no significant change in the current-voltage relation in the range of potentials $(0$ to -50 $\mathrm{mV}$ ) where measurements of junctional conductance were taken in cell pairs. Similar results were obtained from five other solitary cells with $50 \mu \mathrm{M}$ dopamine and six cells with $100 \mu \mathrm{M}$ dopamine.

To determine if dopamine exerts its effects on zebrafish horizontal cell coupling through binding to a dopamine receptor, the ability of dopaminergic agonists to stimulate uncoupling was tested. Application of $100 \mu \mathrm{M}$ ADTN (Creese and Snyder, 1978;
Seeman et al., 1979), a nonspecific dopamine agonist capable of both receptor binding and full activation of adenylate cyclase in the carp retina (Watling and Dowling, 1981), induced uncoupling in four of five cell pairs tested. An example experiment is shown in Figure 10. ADTN acted on the gap junctional conductance with a time course similar to dopamine, and with similar potency. The mean fractional junctional current recorded during uncoupling by ADTN was $0.35( \pm 0.05 \mathrm{SD}, N=4$, see Fig. 13), an approximately threefold reduction in junctional conductance. Other dopamine agonists, SKF38393, a $\mathrm{D}_{1}$-selective agonist, and apomorphine, a nonselective $\mathrm{D}_{2} / \mathrm{D}_{1}$ agonist, produced variable effects on coupling when applied at 100-200 $\mu \mathrm{M}$, inducing increases, decreases, and no effect in different preparations (not shown). This is consistent with previous findings that these two compounds act as only partial agonists of adenylate cyclase activation in the teleost retina, and can, in fact, inhibit adenylate cyclase activity at high concentrations (Watling and Dowling, 1981).

To characterize further the action of dopaminergic agents on zebrafish horizontal cell coupling, the ability of dopamine receptor antagonists to block dopamine's effect on coupling was tested. In these experiments, antagonists were present in the bathing medium at a concentration of $100 \mu \mathrm{M}$, and a mixture of $50 \mu \mathrm{M}$ dopamine and $100 \mu \mathrm{M}$ antagonist was pressure ejected onto the cell pairs. When the selective $\mathrm{D}_{1}$ receptor antagonist SCH23390 was tested in this manner it blocked uncoupling by dopamine in five of five cell pairs tested, suggesting that dopamine acts on zebrafish horizontal cell coupling through a $D_{1}$ type receptor. An example experiment is shown in Figure 11. There is no discernable effect of the $50 \mu \mathrm{M}$ dopamine when coapplied with $\mathrm{SCH} 23390$. The mean junctional current measured $30 \mathrm{sec}$ after application of dopamine and SCH23390 was 0.97 of the control value prior to drug application $( \pm 0.1 \mathrm{SD}$, $N=5$; see Fig. 13). In contrast to the results obtained with $\mathrm{SCH} 23390$, haloperidol, a mixed $\mathrm{D}_{1} / \mathrm{D}_{2}$ receptor antagonist, was not effective at blocking uncoupling by dopamine in zebrafish horizontal cells when tested at a concentration of $100-200 \mu \mathrm{M}$ $(N=2)$.

Both the observed time course of dopamine's action on zebrafish horizontal cell coupling and the apparent involvement of a $D_{1}$ receptor in this mechanism suggested that cAMP may serve as a second messenger for effects on coupling. To test this possibility, the ability of the membrane-permeant cAMP analog 8-bromo-cAMP to induce uncoupling was assayed. Application of $100 \mu \mathrm{M} 8$-bromo-cAMP produced uncoupling in four of five cell pairs tested. As shown in the example experiment (Fig. 12), 8-bromo-cAMP induced uncoupling with a time course and efficacy similar to dopamine and ADTN. The mean fractional junctional current recorded at the peak of 8-bromo-cAMP's effect was 0.37 ( $\pm 0.08 \mathrm{SD}, N=4$; Fig. 13), an approximately threefold reduction in junctional conductance.

Finally, since analysis of coupling coefficients suggested that cell pairs with less than $1 \mathrm{G} \Omega$ extrajunctional resistance may be injured or atypical, I also analyzed the experimental groups in the drug application experiments excluding such cells. In no case were the results significantly altered. When the low extrajunctional resistance cells were excluded, the mean fractional junctional conductance following application of $50 \mu \mathrm{M}$ dopamine was 0.49 ( $\pm 0.19 \mathrm{SD}, 6$ of 7 pairs), for $100 \mu \mathrm{M}$ dopamine it was 0.43 ( $\pm 0.17 \mathrm{SD}, 7$ of 7 pairs), for ADTN it was unchanged, for $\mathrm{SCH} 23390$ it was 1.05 ( $\pm 0.02 \mathrm{SD}, 2$ of 2 pairs), and for 8-bromo-cAMP it was 0.46 ( $\pm 0.06 \mathrm{SD}, 2$ of 3 pairs). 
$I_{\text {j steady state }} / I_{\text {i peak }}$

A

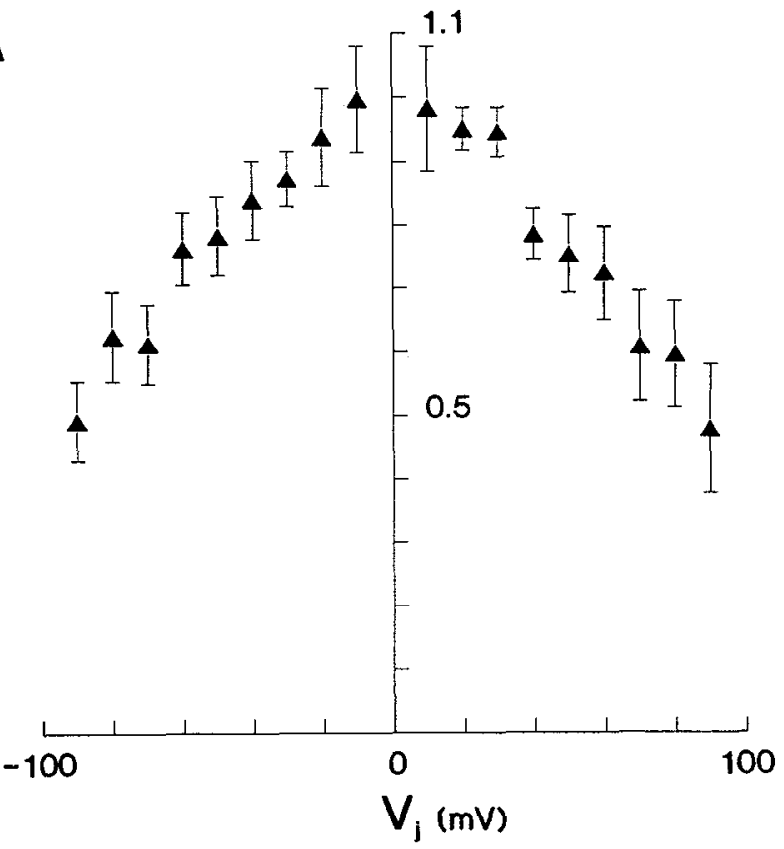

B

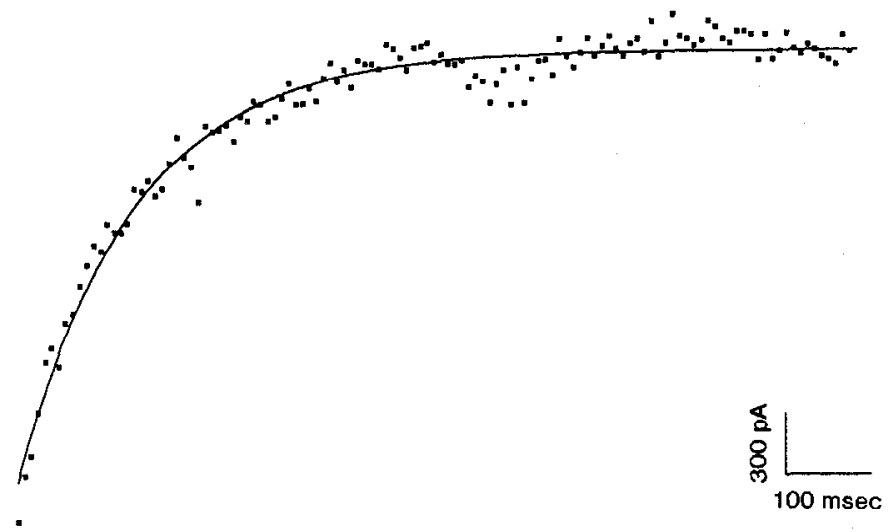

Figure 7. Steady state and kinetic properties of voltage-dependent gating. $A$, Mean ratio of steady state junctional current to peak at transjunctional voltages from -90 to $+90 \mathrm{mV}$ in six horizontal cell pairs $( \pm \mathrm{SEM})$. $B$, Time course of voltage-dependent inactivation of the junctional current as recorded in the follower cell to a voltage step of $+90 \mathrm{mV}$ in the driver cell (inactivation is up). Squares are digitally sampled junctional current (1 $\mathrm{kHz}$ ); curve is fit of single exponential with a time constant of $133 \mathrm{msec}, r=0.985$.
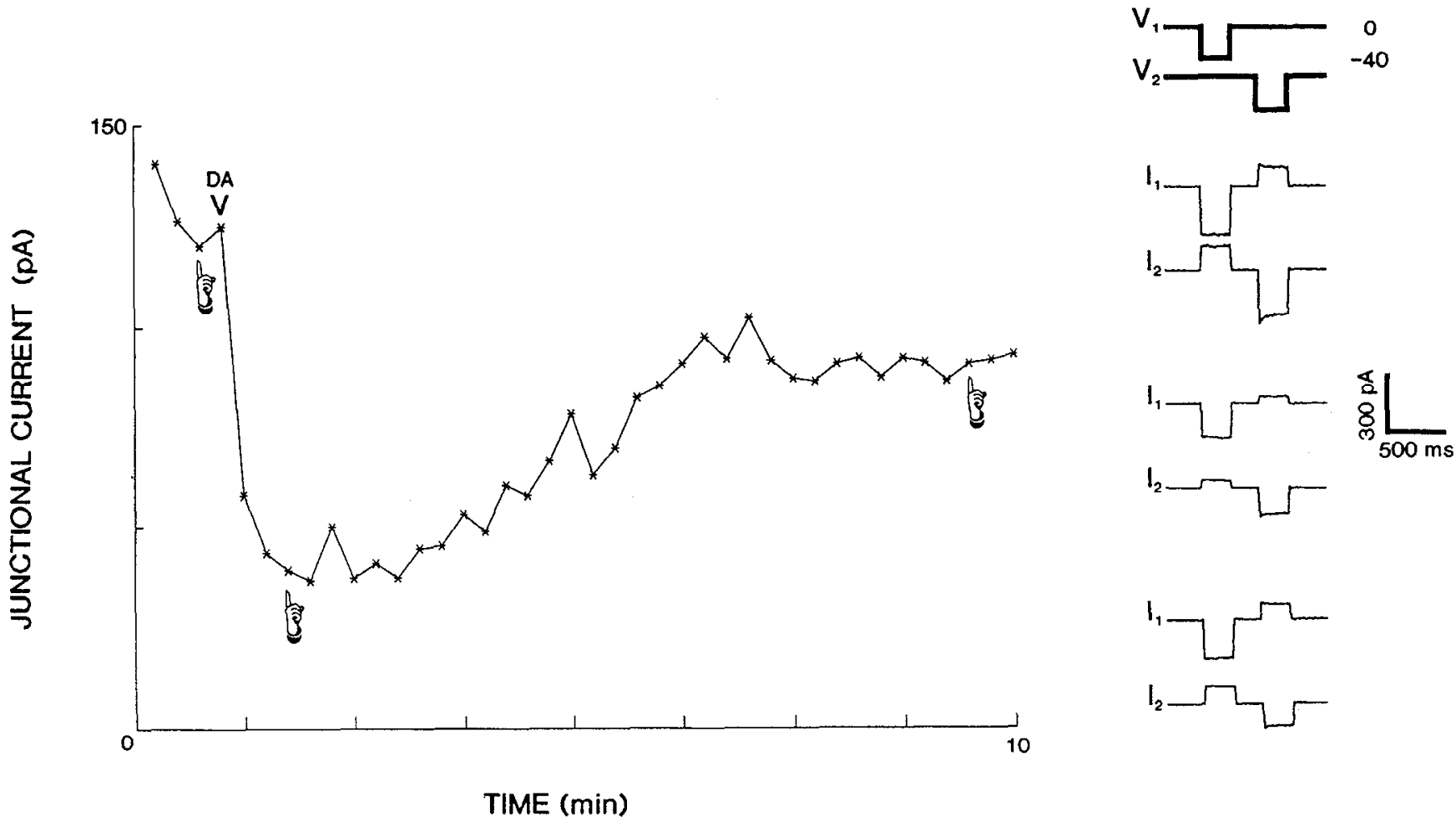

TIME (min)

Figure 8. Effect of dopamine on junctional conductance. Main panel shows junctional current in response to a $-40 \mathrm{mV}$ voltage steps delivered every $15 \mathrm{sec}$. Pointers identify sample episodes displayed top to bottom on the right (voltage traces are hand drawn). At arrowhead a 2 sec puff of $50 \mu \mathrm{M}$ dopamine $(D A)$ was applied to the cell pair, resulting in a reduction in the junctional current. 


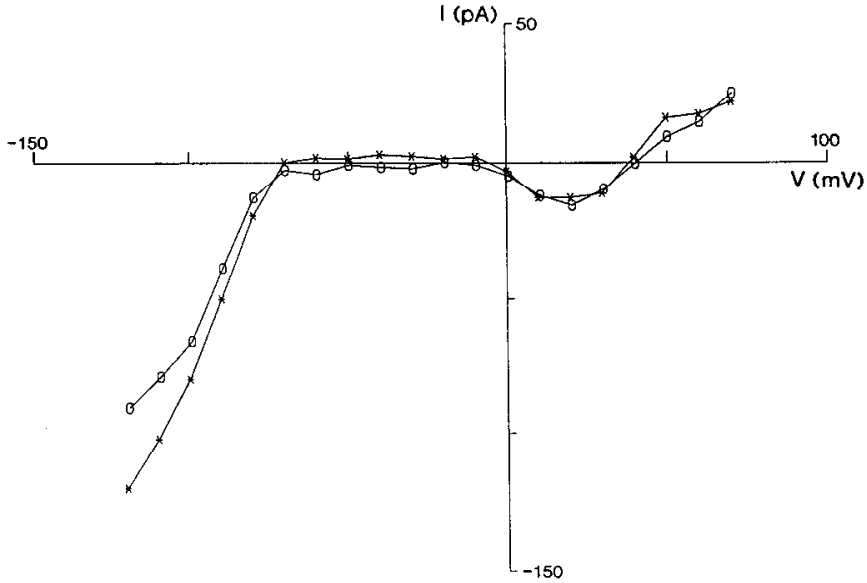

rigure 9. Lack of effect of dopamine on extrajunctional conductances. Steady state current-voltage relations taken before $(X)$ and $30 \mathrm{sec}$ after $(O)$ application of $50 \mu \mathrm{M}$ dopamine.

This indicates that the relatively low sensitivity of the gap junctions between these cells to dopamine and its agonists is not due to damage from recording.

\section{Discussion}

The principle findings of this study are that the electrical synapses of zebrafish retinal horizontal cells are gated by transjunctional voltage, and modulated by the neurotransmitter dopamine and by cAMP. In addition, the results indicate that zebrafish horizontal cells are unique among teleost horizontal cells in exhibiting low levels of junctional conductance and sensitivity to dopamine in vitro. These quantitative differences in the properties of zebrafish horizontal cell electrical synapses have important implications for the function of the horizontal network in the intact retina, and suggest that there are speciesspecific differences in the mechanisms that regulate the expression of electrical coupling in the teleost retina.

Voltage-dependent gating of horizontal cell gap junctions varies among teleost species examined. In this study I have found that the junctional conductance exhibited partial inactivation that increased with increasing transjunctional voltage, which is also the case in the catfish (DeVries and Schwartz, 1992). In contrast, the junctional conductance of horizontal cells from the white perch was reported to be independent of junctional voltage (Lasater and Dowling, 1985b). However, in that study the voltage sensitivity was tested over a smaller range of junctional potentials, from 0 to $40 \mathrm{mV}$, a range in which zebrafish horizontal cell gap junctions show little voltage-dependent inactivation. The voltage dependence of several members of the connexin gene family have been tested by expression of connexin proteins in pairs of Xenopus oocytes. Mammalian connexins cx32 and cx26 exhibit distinct forms of voltage-dependent closure (Spray et al., 1991), as does Xenopus connexin cx38 (Ebihara et al., 1989). Rat connexin cx43 does not exhibit voltage dependence in cardiac myocyte gap junctions (Spray and Bennett, 1985), but human cx43 does exhibit voltage dependence similar to that of zebrafish horizontal cell gap junctions when transfected and expressed in a communication-deficient cell line (Moreno et al., 1992). This distinctive pattern of voltage sensitivities suggests that characteristic voltage dependence of zebrafish horizontal cell gap junctions will be useful in establishing the homology of the connexin protein(s) in this junction to other connexins.

In addition to being gated by junctional voltage, the junctional conductance of zebrafish horizontal cells is modulated by dopamine and cAMP. The effect of dopamine is specific for the junctional conductance, as indicated by the lack of effect on the steady state currents in the extrajunctional membrane. The action of dopamine is completely blocked by the selective $\mathrm{D}_{1}$
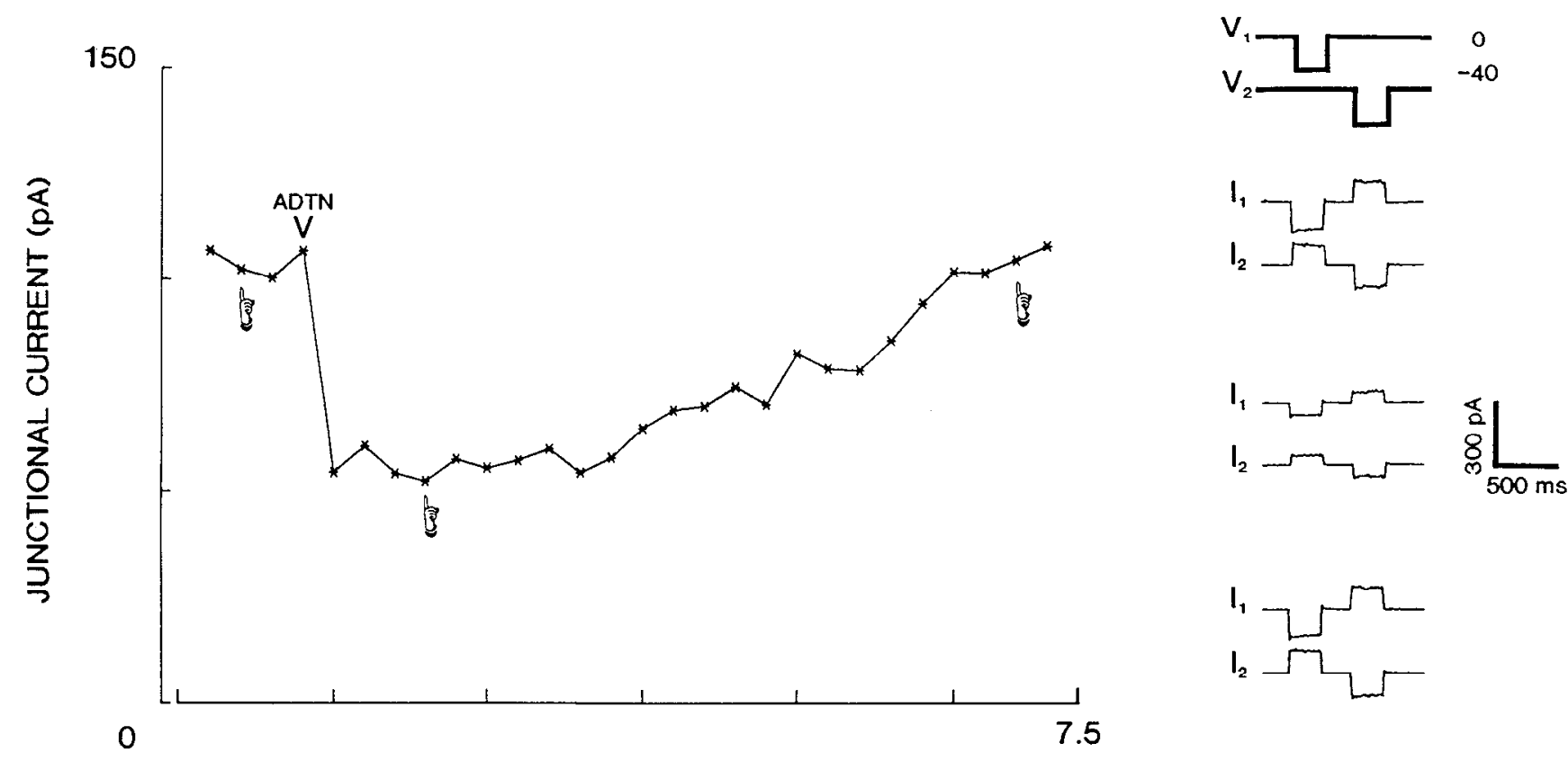

TIME (min)

Figure 10. Effect of the dopaminergic agonist ADTN on junctional conductance. Format is the same as in Figure 8 but with $100 \mu \mathrm{M}$ ADTN applied at the arrowhead. 

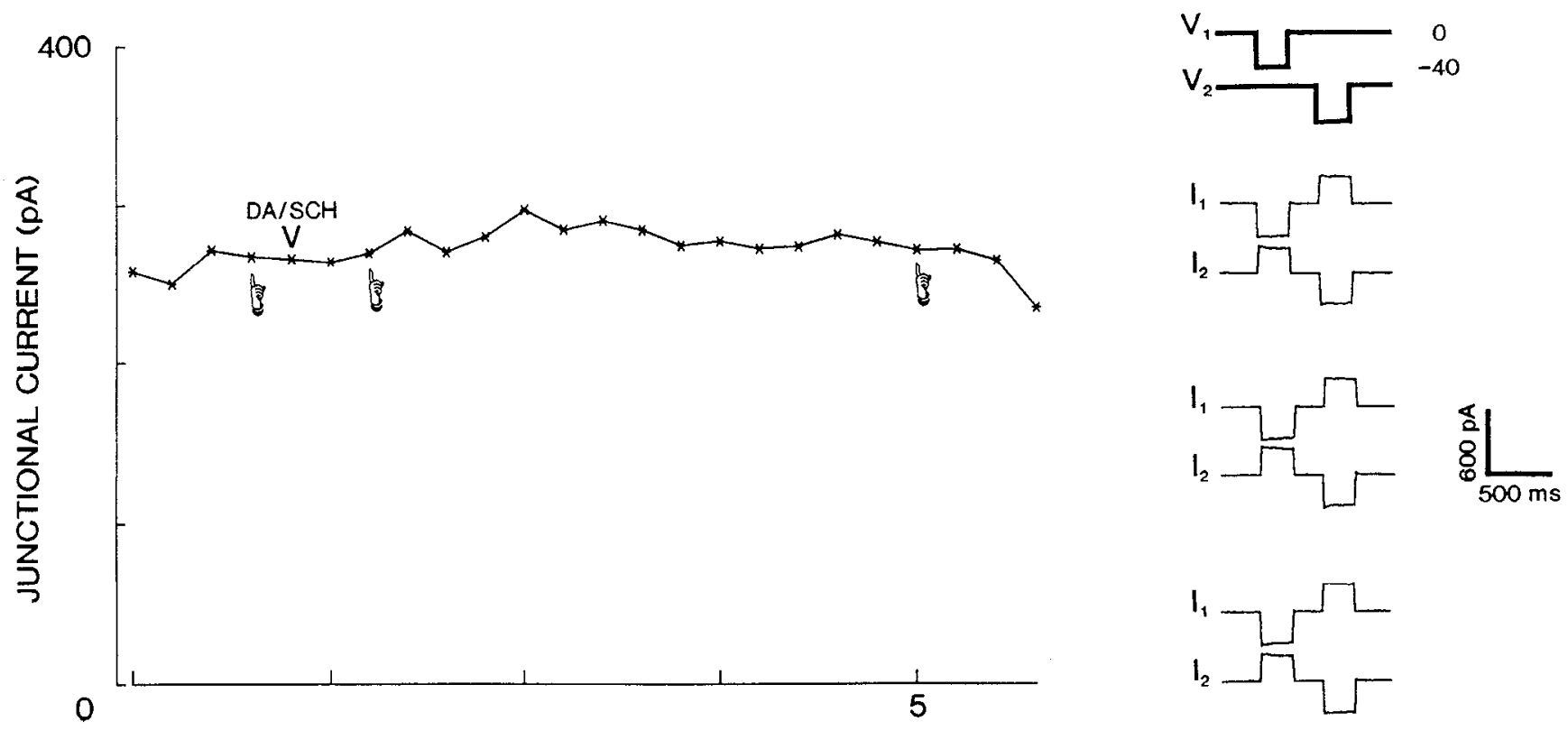

TIME (min)

Figure 11. Blockade of dopamine effect by SCH23390. Format is the same as in Figurc 8, but with $50 \mu \mathrm{M}$ dopaminc $(D A)$ and $100 \mu \mathrm{M}$ SCH23390 $(S C H)$ coapplied at the arrowhead.

receptor antagonist $\mathrm{SCH} 23390$, and is mimicked by application of the membrane-permeant cAMP analog 8-bromo-cAMP. Taken together, these results strongly suggest that dopamine uncouples zebrafish horizontal cells by acting on a $D_{1}$-type receptor and increasing intracellular cAMP levels in a manner similar to its action on horizontal cells in other teleost species (Lasater and Dowling, 1985a; Lasater, 1987; DeVries and Schwartz, 1989). Additional indirect support for the role of cAMP in uncoupling zebrafish horizontal cells comes from the results using SKF38393 and apomorphine. These partial agonists for activation of adenylate cyclase in the fish retina (Watling and Dowling, 1981) do not fully mimic the action of dopamine on junctional conductance. In white bass and catfish horizontal cells it has been demonstrated that cAMP modulates junctional conductance through activation of protein kinase $A$ (Lasater, 1987; DeVries and Schwartz, 1989). This remains to be established in the zebrafish.

In a topologically ordered neural network such as the outer
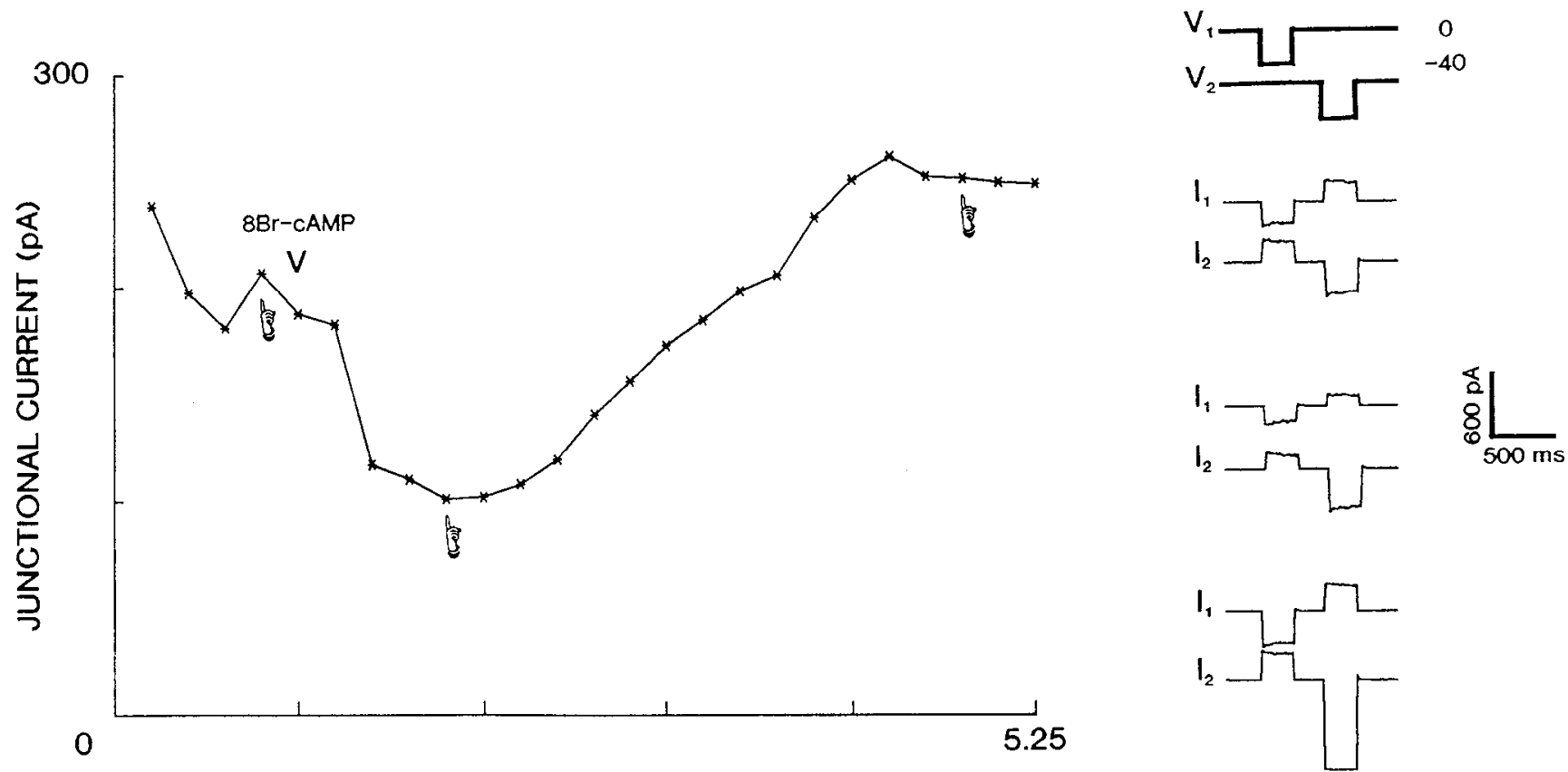

TIME (min)

Figure 12. Effect of 8-bromo-cAMP on junctional conductance. Format is the same as Figure 8, but with $100 \mu \mathrm{M} 8$-bromo-cAMP (8Br-cAMP) applied at the arrowhead. 


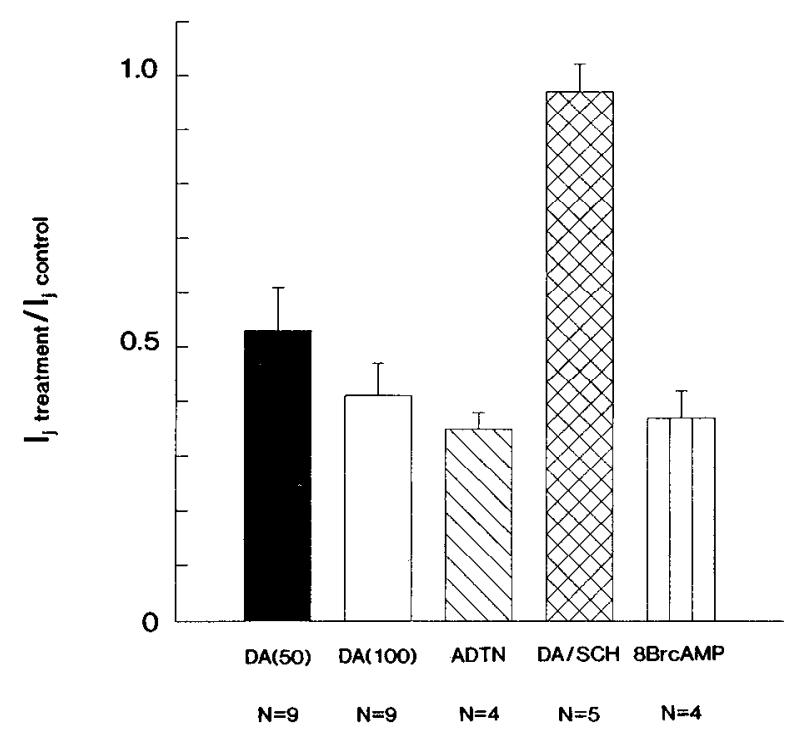

Figure 13. Summary of effects of dopaminergic agonists and antagonists on junctional conductance. Bars are mean fractional junctional current \pm SEM.

plexiform layer of the retina, the strength of electrical coupling between neurons influences the extent of spatial integration in the network. The comparatively poor electrical coupling of zebrafish horizontal cells may represent an adaptation of horizontal cell network properties to visual function in the small eye of a visual predator, where spatial resolution is at a premium. The absolute magnitude of the junctional conductance in the zebrafish is approximately 10 -fold lower than the junctional conductance of other teleost horizontal cells in primary cell culture (Lasater and Dowling, 1985a; Lasater, 1987; DeVries and Schwartz, 1989). If the values for junctional conductance between zebrafish horizontal cells measured in vitro faithfully reflect coupling parameters in vivo, then the length constant for electrotonic transmission in the horizontal cell network is greatly reduced in the zebrafish retina. While the actual length constant of the horizontal cell network in vivo is a product of cell spacing and extrajunctional resistance as well as junctional conductance, a 10-fold decrease in the junctional conductance alone would reduce the length constant by $\vee 10$, or approximately threefold, based on the formula for calculating the resistance of a twodimensional sheet (Piccolino et al., 1984). The functional consequence of this would be to reduce the spread of inhibitory signals in the horizontal cell network, thereby reducing receptive field size. Reducing the size of horizontal cell receptive fields, which mediate lateral inhibition in bipolar and ganglion cell receptive fields, could help maintain visual resolution in the zebrafish eye, where the optical image falling on the retina is small.

The theoretical limits of visual resolution are set by the relationship between the size of the optical image falling on the retina and photoreceptor spacing (von Helmholtz, 1924). However, behaviorally measured visual resolution in goldfish $(1.8 \times$ theoretical, Northmore and Dvorak, 1979), skipjack (1.2×, Nakamura, 1968), and the young zebrafish (1.7×, Clark, 1981) falls short of theoretical. The fact that the optical resolution of the lens is not limiting (Tamura, 1957) suggests that spatial summation in the neural retina (i.e., signal pooling in photoreceptors and horizontal cells) plays a role in determining the in vivo acuity. Both eye size and the variations in visual function associated with different ecological niches would be expected to affect the characteristics of spatial summation in the horizontal cell network. In comparison with other species used to study horizontal cell electrical coupling, zebrafish are relatively small and are visual predators of small aquatic life including paramecia (Clark, 1981), and thus need high-acuity vision. Measurement of eye size in 11 animals from our colony indicated that eye diameter ranged from 1.5 to $2.5 \mathrm{~mm}$, and the diameter of flat mounted retinas ranged from 2.5 to $3.0 \mathrm{~mm}$. In comparison, the mean diameter of adult white perch eyes estimated from their displaced volume is $12 \mathrm{~mm}$ (D. G. McMahon, unpublished observations), and the receptive field size of individual horizontal cells is $1-3 \mathrm{~mm}$ (Tornqvist et al., 1988). In other species that also have larger eyes and are not visual predators, such as the catfish, skate, and dogfish, horizontal cell receptive fields ranged from 0.2 to more than $2 \mathrm{~mm}$ (Naka and Rushton, 1967; Dowling and Ripps, 1971; Kaneko, 1971; Davis and Naka, 1980 ), values that would be inappropriately large for horizontal cells in the zebrafish retina. Interestingly, measurements of junctional conductance from a closely related species, the giant danio (Danio aequipinnatus), which is intermediate in eye size between the zebrafish and the larger teleosts (i.e., white perch, catfish), show that the junctional conductance is also of intermediate magnitude (McMahon and Marcinek, 1992). Although further systematic study is needed, the available data are suggestive of a correlation between the required resolving power of the eye, horizontal cell receptive field size, and the magnitude of the horizontal cell gap junctional conductance. This correlation implies the existence of an intrinsic mechanism, perhaps one influencing synaptic assembly and maintenance, regulating the level of electrical coupling in horizontal cells of different teleost species.

The two- to threefold average reduction in coupling brought about by application of dopamine, ADTN, and 8-bromo-cAMP to zebrafish horizontal cells is also substantially less than the 10-fold reductions in junctional conductance observed in other teleost horizontal cells at similar or lower dopamine concentrations (Lasater and Dowling, 1985a; Lasater, 1987; DeVries and Schwartz, 1989). Since doubling the concentration of applied dopamine from 50 to $100 \mu \mathrm{M}$ produced only a small increase in uncoupling, it is likely that the responses reported in this study represent near maximal uncoupling by dopamine and its agonists in the zebrafish. One possible explanation for the more modest changes in junction conductance observed in the zebrafish is that there is a substantial subpopulation of junctional channels that are unaffected by dopamine and cAMP in these junctions. This is unlikely because dopaminergic modulation is observed even in cell pairs with junctional conductances of 0.1 $\mathrm{nS}$ (i.e., two active gap junction channels) or below (McMahon, 1992), and in these junctions dopamine can, at its peak effect, transiently suppress junctional channel activity. An alternative explanation is related to the issue of scaling the physiological properties of the horizontal cell network to adapt it to the constraints of this small vertebrate eye. Given the already low junctional conductance of zebrafish horizontal cells, these less dramatic changes in junctional conductance may be appropriate to modulate the receptive field properties of horizontal cells in vivo.

While rapid modulation of electrical coupling is apparently accomplished by covalent modification of existing junctional channels, the mechanisms of synaptic assembly and maintenance are likely to play an important role in electrical synaptic 
plasticity taking place on a longer time scale. For example, the expression of specific connexin genes is developmentally regulated in the mammalian brain (Dermietzel et al., 1989) and the extent of neuronal dye coupling is decreased in the cortex during developmental maturation (Peinado et al., 1993) and increased in the hippocampus during aging (Barnes et al., 1987). In the retina, the structure of horizontal cell electrical synapses is altered by light adaptation or prolonged exposure to dopamine (Kurz-Isler and Wolburg, 1988; Baldridge et al., 1989). In this regard, the cellular mechanisms that apparently differentially regulate the strength of electrical synaptic transmission in horizontal cells of different teleost species are of interest. A priori, this regulation could involve different levels of expression of gap junction channel proteins, posttranslational modification of channels affecting the probability of channels being in the open and conducting state, or differences in the conducting properties of gap junction channels. The unitary conductance of both white perch and zebrafish horizontal cell gap junction channels is in the 50-60 pS range (McMahon et al., 1989; McMahon and Brown, 1984), suggesting that the lower junctional conductance of zebrafish cell pairs is not due to differences in the conducting properties of individual channels but, in fact, reflects differences in the average number of conducting channels in the junctions of these two species. It is unlikely that these differences are a simple reflection of differences in contact area. Cell pairs of both species typically exhibit membrane appositions several micrometers in length in culture and connexon density in teleost horizontal cell gap junctions is typically several thousand per square micrometer (Kurz-Isler and Wolburg, 1988; Baldridge et al., 1989). Yet, the observed levels of conductance represent only $20-40$ open channels on average in the zebrafish and 200-400 open channels in the white perch. Determining whether this is due to differences in the overall number of gap junction channels (i.e., levels of expression of connexin proteins) in these junctions or in the proportion of expressed channels that are physiologically active will require molecular probes for teleost gap junction channel genes and proteins. The identity and structure of the horizontal cell gap junction channel protein are yet to be elucidated; however, preliminary experiments indicate gene sequences homologous to mammalian gap junction genes are present in the zebrafish and giant danio genomes (D. G. McMahon, D. L. Paul, and T. L. Edgerton, unpublished observations). In addition, the expression of electrical coupling between horizontal cells of the giant danio is reduced in low-calcium culture medium, suggesting a role for cell calcium in regulating synaptic assembly and maintenance (McMahon et al., 1993).

In summary, the electrical synapses of zebrafish retinal horizontal cells have characteristics that are qualitatively similar but quantitatively different from those described in other teleosts. These quantitative differences reflect differences in the regulation of synaptic assembly and maintenance and have important implications for the function of zebrafish horizontal cells in vivo. Their lower junctional conductance and responsivity to dopamine may be adaptations for network function in a relatively small eye of a visual predator, a hypothesis that must be tested by recording from horizontal cells in the retina rather than from dissociated cells. The high input resistance of zebrafish horizontal cells combined with their relatively small membrane area and low junctional conductance make these cells a particularly attractive preparation for studying electrical synaptic transmission and its modulation at the single-channel level. Initial studies indicate that dopamine modifies the gating kinetics of zebrafish horizontal cell gap junction channels, reducing their open probability (McMahon, 1992; McMahon and Brown, 1984). Studies of horizontal gap junction channel modulation at the single-channel level, combined with identification of the channel protein and elucidation of its sequence and structure, will help reveal molecular mechanisms of electrical synaptic plasticity.

\section{References}

Baldridge WH, Ball AK, Miller RG (1989) Gap junction particle density of horizontal cells in goldfish retinas lesioned with 6-OHDA. J Comp Neurol 287:238-246.

Barnes CA, Rao G, McNaughton BL (1987) Increased electrotonic coupling in aged rat hippocampus: a possible mechanism for cellular excitability changes. J Comp Neurol 259:549-558.

Cepeda C, Walsh JP, Hull CD, Howard SG, Buchwald NA, Levine MS (1989) Dye coupling in the neostriatum of the rat. I. Modulation by dopamine-depleting lesions. Synapse 4:229-237.

Christie MJ, Williams JT, North RA (1989) Electrical coupling synchronizes subthreshold activity in locus coeruleus neurons in vitro from neonatal rats. J Neurosci 9:3584-3589.

Clark DT (1981) Visual responses in developing zebrafish (Brachydanio rerio). Ph.D. thesis, University of Oregon.

Cobbett P, Yang QZ, Hatton GI (1987) Incidence of dye coupling among magnocellular paraventricular nucleus neurons in male rats is testosterone dependent. Brain Kes Bull 18:365-370.

Connors BW, Bernardo LS, Prince DA (1983) Coupling between neurons of the developing rat neocortex. J Neurosci 3:773-782.

Creese I, Snyder SH (1978) Dopamine receptor binding of $\mathrm{H}_{3}-\mathrm{ADTN}$ (2-amino-6,7-dihydroxy-1,2,3,4-tetrahydronaphthalene) regulated by guanyl nucleotides. Eur J Pharmacol 50:459-461.

Culp P, Nusslein-Volhard C, Hopkins N (1991) High-frequency germline transmission of plasmid DNA sequences injected into fertilized zcbrafish cggs. Proc Natl Acad Sci USA 88:7953-7957.

Davis GW, Naka KI (1980) Spatial organizations of catfish retinal neurons. I. Single and random bar stimulation. J Neurophysiol 43: 807-841.

Dermietzel R, Traub O, Hwang TK, Beyer E, Bennett MVL, Spray DC, Willecke K (1989) Differential expression of three gap junction proteins in developing and mature brain tissues. Proc Natl Acad Sci USA 86:10148-10152.

DeVries SH, Schwartz EA (1989) Modulation of an electrical synapse between solitary pairs of catfish horizontal cells by dopamine and second messengers. J Physiol (Lond) 414:351-375.

DeVries SH, Schwartz EA (1992) Hemi-gap-junction channels in solitary horizontal cells of the catfish retina. J Physiol (Lond) 445:201230.

Dong C-J, McReynolds JS (1991) The relationship between light, dopamine release and horizontal cell coupling in the mudpuppy retina. J Physiol (Lond) 440:291-309.

Dowling JE (1987) The retina: an approachable part of the brain. Cambridge, MA: Belknap.

Dowling JE, Ehinger B (1978) The interplexiform cell system. I. Synapses of the dopaminergic neurons of the goldfish retina. Proc $\mathrm{R}$ Soc Lond [Biol] 201:7-26.

Dowling JE, Ripps H (1971) S-potentials in the skate retina. Intracellular recording during light and dark adaptation. J Gen Physiol 58: 163-189.

Dowling JE, Pak MW, I asater FM (1982) White perch horizontal cells in culture: methods, morphology and process growth. Brain Res 360 : 331-338.

Ebihara L, Beyer EC, Swenson KI, Paul D, Goodenough DA (1989) Cloning and expression of a Xenopus embryonic gap junction protein. Science 243:1194-1195.

Fulwiler C, Mayer-Benegas N, Dowling JE (1989) The development of putative GABAergic and dopaminergic neurons in the retina of the zebrafish Brachydanio rerio. Soc Neurosci Abstr 15:1209.

Fulwiler C, Yelick P, Gilbert W (1992) In vivo imaging of gene expression in zebrafish embryos: an insertional mutagenesis approach to neural development. Soc Neurosci Abstr 22:955.

Furshpan EJ, Potter DD (1959) Transmission at the giant motor synapses of the crayfish. J Physiol (Lond) 145:289-325. 
Giaume C, Kado RT, Korn H (1987) Voltage-clamp analysis of a crayfish rectifying synapse. J Physiol (Lond) 386:91-112.

Hamill O, Marty A, Neher E, Sakmann B, Sigworth FJ (1981) Improved patch-clamp techniques for high resolution current recording from cells and cell-free membrane patches. Pfluegers Arch 391:85100 .

Hampson E, Weiler R, Vaney DI (1992) Regulation of gap junction permeability between A-type horizontal cells in the rabbit retina: effects of pH and dopamine. Invest Ophthalmol Vis Sci [Suppl] 33: 1406.

Harris AL, Spray DC, Bennett MVL (1981) Kinetic properties of a voltage-dependent junctional conductance. J Gen Physiol 77:95-117.

Kaneko A (1971) Electrical connexions between horizontal cells in the dogfish retina. J Physiol (Lond) 213:95-105.

Knapp AG, Dowling JE (1987) Dopamine enhances excitatory amino acid-gated conductances in retinal horizontal cells. Nature 325:437439.

Kurz-Isler G, Wolberg H (1988) Light-dependent dynamics of gap junctions between horizontal cells in the retina of the crucian carp. Cell Tissue Res 251:641-649.

Lasater EM (1986) Ionic currents form cultured horizontal cells isolated from white perch. J Neurophysiol 55:499-513.

Lasater EM (1987) Retinal horizontal cell gap junctional conductance is modulated by dopamine through a cAMP-dependent protein kinase. Proc Natl Acad Sci USA 84:7319-7323.

Lasater EM, Dowling JE (1985a) Dopaminc decreases conductance of the electrical junctions between cultured retinal horizontal cells. Proc Natl Acad Sci USA 82:3025-3029.

Lasater EM, Dowling JE (1985b) Electrical coupling between pairs of isolated fish horizontal cells is modulated by dopamine and cAMP. In: Gap junctions (Bennett MVL, Spray DC, eds), pp 393-404. Cold Spring Harbor, NY: Cold Spring Harbor Laboratory.

Llinas R (1985) Electrotonic transmission in the mammalian central nervous system. In: Gap junctions (Bennett MVL, Spray DC, eds), pp 337-353. Cold Spring Harbor, NY: Cold Spring Harbor Laboratory.

MacVicar BA, Dudek FE (1981) Electrotonic coupling between pyramidal cells: a direct demonstration in rat hippocampal slices. Science 213:782-785.

Matsumoto $\Lambda, \Lambda$ rnold $\Lambda$ P, Zampighi GE, Miccvych PE (1988) Androgenic regulation of gap junctions between motor neurons in the rat spinal cord. J Neurosci 8:4177-4183.

McMahon DG (1992) Dopamine reduces channel open time in zebrafish horizontal cell electrical synapses. Soc Neurosci Abstr 18:839.

McMahon DG, Brown DR (1994) Modulation of gap junction channel gating mediates plasticity at a retinal electrical synapse. Submitted.

McMahon DG, Marcinek RG (1992) Dopamine modulates horizontal cell electrical synapses in the zebrafish and giant danio. Invest Ophthalmol Vis Sci 33:1405.

McMahon DG, Knapp AG, Dowling JE (1989) Horizontal cell gap junctions: single channel conductance and modulation by dopamine. Proc Natl Acad Sci USA 86:7639-7643.

McMahon DG, Mattson MP, Crager JL (1993) Role for cell calcium in regulating expression of electrical coupling and ncurite outgrowth in horizontal cells from the giant danio. Invest Ophthalmol Vis Sci $34: 2210$.

Moreno AP, Fishman GI, Spray DC (1992) Phosphorylation shifts unitary conductance and modifies voltage-dependent kinetics of human connexin 43 gap junction channels. Biophys $\mathrm{J} 62: 48-50$.

Naka KI, Rushton WAH (1967) The generation and spread of S-potentials in fish (Cyprinidae). J Physiol (Lond) 192:437-461.

Nakamura E (1968) Visual acuity of two tunas, Katsuwonus pelamis and Euthynnus affinis. Copeia 1968:41-49.

Negishi K, Drujan BD (1979) Reciprocal changes in center and surrounding S-potentials of fish retina in response to dopamine. Neurochem Res 4:313-318.

Neyton J, Trautmann A (1985) Single channel currents of an intercellular junction. Nature 317:331-335.
Northmore DPM, Dvorak CA (1979) Contrast sensitivity acuity of the goldfish. Vision Res 19:255-261.

O'Donnell P, Grace AA (1991) Dye coupling is differentially affected by apomorphine in accumbens shell and core neurons. Soc Neurosci Abstr 17:456.

Onn S-P, Berger TW, Grace AA (1991) Dye coupling in type I and type II striatal neurons: alteration by apomorphine and localization to the patch/matrix. Soc Neurosci Abstr 17:850.

Peinado A, Yuste R, Katz LC (1993) Extensive dye coupling between rat neocortical neurons during the period of circuit formation. Neuron 10:103-114.

Perlman I, Knapp AG, Dowling JE (1988) Local superfusion modifies the inward rectifying potassium conductance of isolated horizontal cells. J Neurophysiol 60:1322-1332.

Piccolino M, Neyton J, Gerschenfeld HM (1984) Decrease in gap junctional conductance induced by dopamine and cyclic adenosine $3^{\prime}: 5^{\prime}$-monophosphate in horizontal cells of the turtle retina. J Neurosci $4: 2477-2488$.

Seeman P, Woodruff GN, Poat JA (1979) Similar binding of ${ }^{3} \mathbf{H}-$ ADTN and ${ }^{3} \mathrm{H}$-apomorphine to calf brain dopamine receptors. Fur J Pharmacol 55:137-142.

Shingai R, Christensen BN (1983) Sodium and calcium currents measured in isolated catfish horizontal cells under voltage clamp. Neuroscience 10:893-897.

Spray DC, Bennett MVL (1985) Physiology and pharmacology of gap junctions. Annu Rev Physiol 47:281-303.

Spray DC, Bennett MVL, Campos de Carvalho AC, Eghbali B, Moreno AP, Verselis VK (1991) Transjunctional voltage-dependence of gap junction channels. In: Gating of gap junction channels (Peracchia $\mathrm{C}$, ed), pp 97-116. Boca Raton, FL: CRC.

Stell WK, Lightfoot DO (1975) Color-specific interconnections of cones and horizontal cells in the retina of the goldfish. J Comp Neurol 159: 473-502.

Streisinger G, Walker C, Dower N, Knauber D, Singer F (1981) Production of clones of homozygous diploid zebra fish (Brachydanio rerio). Nature 291:293-296.

Stuart GW, McMurray JV, Westerfield M (1988) Replication, integration and stable germ-line transmission of foreign sequences injected into early zebrafish embryos. Development 103:403-412.

Sullivan JM, Lasater EM (1990) Sustained and transient potassium currents of cultured horizontal cells isolated from the white bass retina. J Neurophysiol 64:1758-1766.

Tachibana M (1983) Ionic currents of solitary horizontal cells isolated from the goldfish retina. J Physiol (Lond) 345:329-351.

Tamura $T$ (1957) A study of visual perception in fish, especially on resolving power and accommodation. Bull Jpn Soc Sci Fish 22:536557.

Teranishi T, Negishi K, Kato S (1983) Dopamine modulates S-potential amplitude and dye coupling between external horizontal cells in carp retina. Nature 301:243-246.

Tornqvist K, Yang X-L, Dowling JE (1988) Modulation of cone horizontal cell activity in the teleost fish retina. III. Effects of prolonged darkness and dopamine on electrical coupling between horizontal cclls. J Ncurosci 8:2279-2288.

Van Buskirk R, Dowling JE (1981) Isolated horizontal cells from carp retina demonstrate dopamine-dependent accumulation of cyclic AMP. Proc Natl Acad Sci USA 78:7825-7829.

Verselis V, Bennett MVL, Bargiello TA (1991) A voltage-dependent gap junction in Drosophila melanogaster. Biophys J 59:114-126.

von Helmholtz H (1924) Helmholtz's treatise on physiological optics, Vols 1-3 (Southhall JPC, ed). Rochester, NY: Optical Society of America.

Watling KJ, Dowling JE (1981) Dopaminergic mechanisms in the teleost retina I. Dopamine-sensitive adenylate cyclase in homogenates of carp retina: effects of agonists, antagonists and ergots. J Neurochem 36:559-568.

Yuste R, Peinado A, Katz LC (1992) Neuronal domains in developing neocortex. Sciencc 257:665-669. 